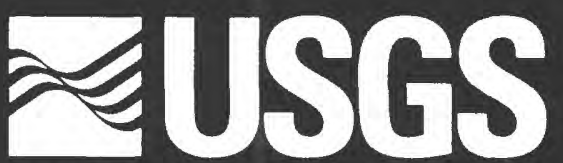

science for a changing world

Prepared in cooperation with the ARKANSAS SOIL AND WATER CONSERVATION COMMISSION

\title{
SUSTAINABLE-YIELD ESTIMATION FOR THE SPARTA AQUIFER IN UNION COUNTY, ARKANSAS
}

Water-Resources Investigations Report 99-4274

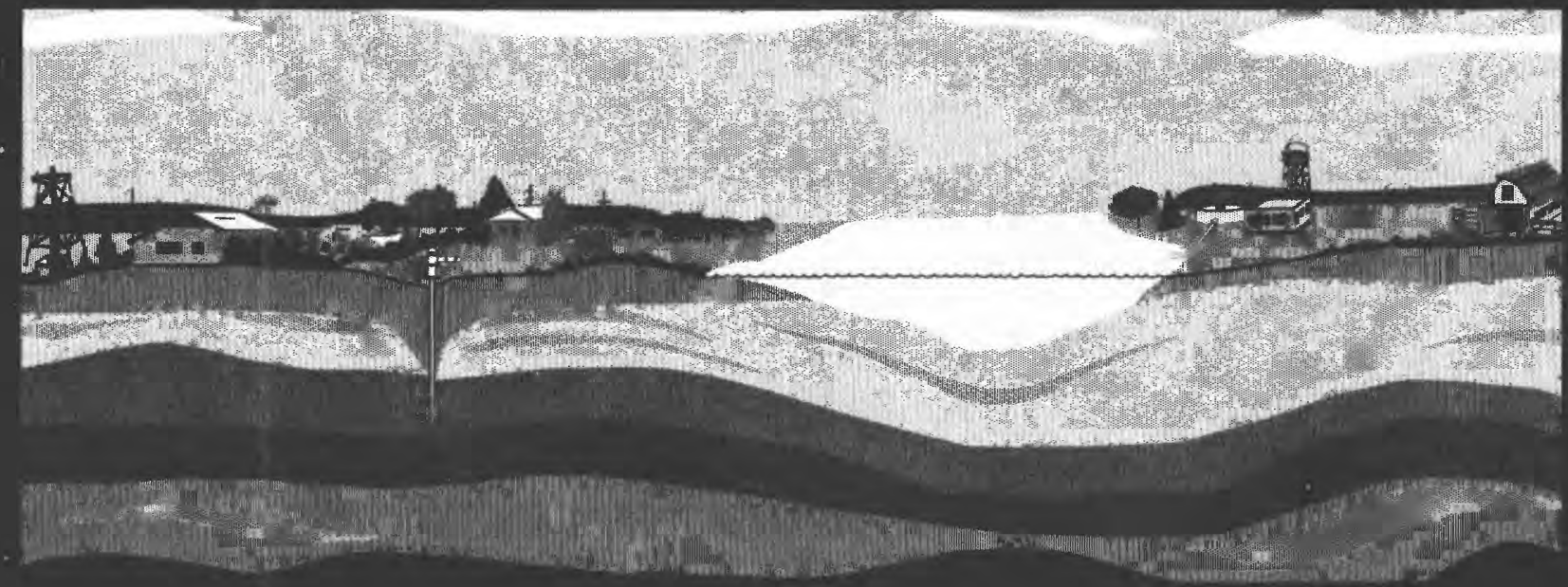

U.S. Department of the Interior

U.S. Geological Survey 
U.S. Department of the Interior

U.S. Geological Survey

SUSTAINABLE-YIELD ESTIMATION FOR THE SPARTA AQUIFER IN UNION COUNTY, ARKANSAS

By Phillip D. Hays

U.S. GEOLOGICAL SURVEY

Water-Resources Investigations Report 99-4274

Prepared in cooperation with the ARKANSAS SOIL AND WATER CONSERVATION COMMISSION 


\section{U.S. DEPARTMENT OF THE INTERIOR \\ BRUCE BABBITT, Secretary}

\section{U.S. GEOLOGICAL SURVEY}

Charles G. Groat, Director

The use of firm, trade, and brand names in this report is for identification purposes only and does not constitute endorsement by the U.S. Government

For additional information write to:

District Chief U.S. Geological Survey, WRD 401 Hardin Road Little Rock, Arkansas 72211
Copies of this report can be purchased from:

U.S. Geological Survey Branch of Information Services Box 25286 Denver Federal Center Denver, Colorado 80225 


\section{CONTENTS}

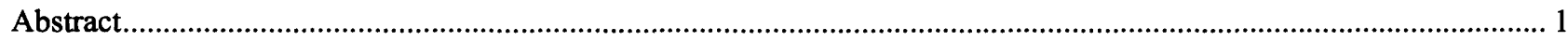

Introduction

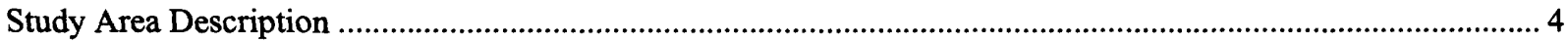

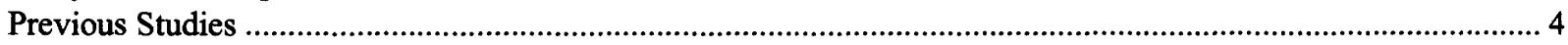

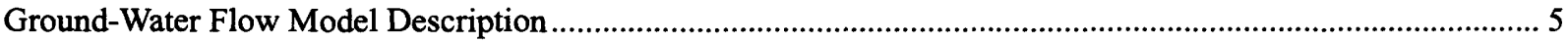

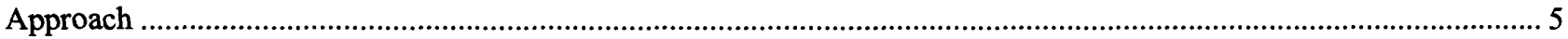

Sustainable- and Stabilization-Yield Simulation Results ..................................................................................... 7

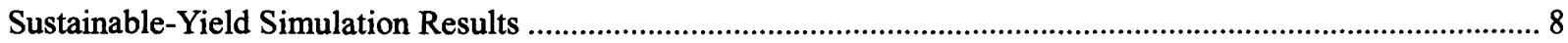

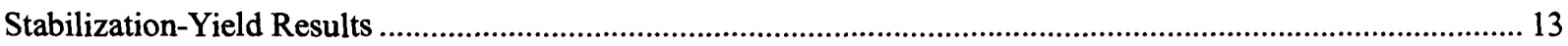

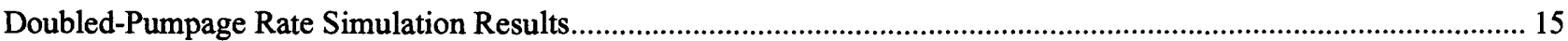

Summary and Conclusions ............................................................................................................................ 15

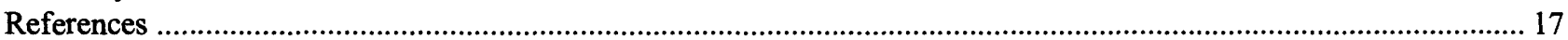

\section{ILLUSTRATIONS}

Figure 1. Map showing location of study and model areas ................................................................................. 3

2. Diagrammatic section of the Sparta aquifer in the Union County area ..................................................... 7

3. Graph showing observed and predicted trend for pumpage from the Sparta aquifer in Union County, Arkansas, 1985-2027; sustainable-yield trend shows how pumpage must change to achieve sustainable yield................. 9

4. Map showing simulated steady state potentiometric surface of the Sparta aquifer with Union County pumpage decreased to 28 percent of 1997 rates (simulation 1a)................................................................... 10

5. Map showing simulated transient potentiometric surface of the Sparta aquifer in 2027 with all pumpage increasing at the 1985-1997 rates

6. Volumetric budget components (entire model) for sustainable-yield scenarios............................................... 12

7. Map showing simulated steady state potentiometric surface of the Sparta aquifer with Union County pumpage decreased to 91 percent of 1997 rates (simulation 3a).

8. Volumetric budget components (entire model) for stabilization-yield scenarios

\section{TABLES}

Table 1. Union County sustainable-yield, stabilization-yield, and doubled-pumpage scenarios ................................. 5

2. Reported and projected pumping estimates for Union County and the model area outside of Union County... 8

3. Sustainable-yield results for the top of the Sparta Sand water-level target for current rate of increase and double current rate of increase pumpage conditions

4. Stabilization-yield results for the top of the El Dorado sand water-level target for current rate of increase and double current rate of increase pumpage conditions. 


\title{
SUSTAINABLE-YIELD ESTIMATION FOR THE SPARTA AQUIFER IN UNION COUNTY, ARKANSAS
}

\author{
By Phillip D. Hays
}

\section{ABSTRACT}

Options for utilizing alternative sources of water to alleviate overdraft from the Sparta aquifer and ensure that the aquifer can continue to provide abundant water of excellent quality for the future are being evaluated by water managers in Union County. Sustainable yield is a critical element in identifying and designing viable water supply alternatives. With sustainable yield defined and a knowledge of total water demand in an area, any unmet demand can be calculated. The ground-water flow model of the Sparta aquifer was used to estimate sustainable yield using an iterative approach.

The Sparta aquifer is a confined aquifer of regional importance that comprises a sequence of unconsolidated sand units that are contained within the Sparta Sand. Currently, the rate of withdrawal in some areas greatly exceeds the rate of recharge to the aquifer and considerable water-level declines have occurred. Ground-water flow model results indicate that the aquifer cannot continue to meet growing water-use demands indefinitely and that water levels will drop below the top of the primary producing sand unit in Union County (locally termed the El Dorado sand) by 2008 if current water-use trends continue. Declines of that magnitude will initiate dewatering of the El Dorado sand.

The sustainable yield of the aquifer was calculated by targeting a specified minimum acceptable water level within Union County and varying Union County pumpage within the model to achieve the target water level. Selection of the minimum target water level for sustainable-yield estimation was an important criterion for the modeling effort. In keeping with the State Critical Ground-Water Area designation criteria and the desire of water managers in Union County to improve aquifer conditions and bring the area out of the
Critical Ground-Water Area designation, the approximate altitude of the top of the Sparta Sand in central Union County was used as the minimum water level target for estimation of sustainable yield in the county. A specific category of sustainable yield - stabilization yield, reflecting the amount of water that the aquifer can provide while maintaining current water levelsalso was determined and provides information for short-term management. The top of the primary producing sand unit (the El Dorado sand) was used as the minimum water-level target for estimating stabilization yield in the county because current minimum water levels in central Union County are near the top of the $\mathrm{El}$ Dorado sand.

Model results show that withdrawals from the Sparta aquifer in Union County must be reduced to 28 percent of 1997 values to achieve sustainable yield and maintain water levels at the top of the Sparta Sand if future pumpage outside of Union County is assumed to increase at the rate observed from 1985-1997. Results of the simulation define a very large current unmet demand and represent a substantial reduction in the county's current dependence upon the aquifer. If future pumpage outside of Union County is assumed to increase at double the rate observed from 1985-1997, withdrawals from the Sparta aquifer in Union County must be reduced to 25 percent of 1997 values to achieve sustainable yield. Withdrawals from the Sparta aquifer in Union County must be reduced to about 88 to 91 percent (depending on pumpage growth outside of the county) of 1997 values to stabilize water levels at the top of the El Dorado sand. This result shows that 1997 rate of withdrawal in the county is considerably greater than the rate needed to halt the rapid decline in water levels. 


\section{INTRODUCTION}

The Sparta aquifer is a confined aquifer of regional importance that comprises a sequence of unconsolidated sand units that are contained within the Sparta Sand. In the Union County area, the informal terms "Green sand" and "El Dorado sand" are applied to the upper and lower major sand units within the Sparta aquifer, respectively. For the sake of clarity, it should be noted that the term "Sparta aquifer" is applied to a sequence of hydraulically connected sands that are often separated by silts and clays and is not an equivalent term with "Sparta Sand"-the formal name for the geologic formation. This distinction is important because by Arkansas law, Critical Ground-Water Area (CGWA) designation criteria are based on the top of the geologic formation rather than the top of the aquifer. Thus, in areas where clays and silts in the Sparta Sand (the geologic formation) occur above productive sands, the top of the Sparta aquifer will not coincide with the top of the Sparta Sand. In this report, the term "Sparta Sand" will always refer to the geologic formation (comprising sands, silts, and clays), and the term "Sparta aquifer" will refer to the sequence of productive, hydraulically connected sands that constitute a part of the geologic formation.

The Sparta aquifer extends across much of eastern and southeastern Arkansas and into adjoining states (fig. 1) and is a principle water resource for municipal, industrial, and agricultural uses. In Arkansas, water use from the aquifer has doubled since 1975 (Holland, 1999). Currently, the rate of withdrawal in some areas greatly exceeds the rate of recharge to the aquifer. Large cones of depression are centered beneath the Grand Prairie area and the cities of Pine Bluff and El Dorado in Arkansas-areas included in CGWAs designated by the Arkansas Soil and Water Conservation Commission (ASWCC). Water levels in the aquifer have declined at rates averaging greater than 1 foot per year $(\mathrm{ft} / \mathrm{yr})$ for more than a decade in areas of southern Arkansas and northern Louisiana (an average decline greater than $4.5 \mathrm{ft} / \mathrm{yr}$ in El Dorado since 1943) (Baker and others, 1948; R.L. Joseph, U.S. Geological Survey, written commun., 1999), and are now below the top of the Sparta Sand in parts of Union County, Arkansas (Joseph, 1998). Results from the regional-scale, digital ground-water flow model for the Sparta aquifer (Hays and others, 1998; Hays and Fugitt, 1999) indicate that the aquifer cannot continue to meet growing water-use demands indefinitely and that water levels will drop below the top of the primary producing sand unit in
Union County (locally termed the El Dorado sand) by 2008 if current water-use trends continue. As water levels decline below the top of the E1 Dorado sand, the sand will begin to dewater, resulting in increased drilling and pumping costs, loss of yield, and decreased water quality.

Sustainable yield (sometimes termed "safe yield") is the volumetric rate of water that an aquifer can provide while maintaining desirable aquifer conditions (primarily water levels and water quality) such that the aquifer remains a viable resource for long-term use. An aquifer managed under sustainable-yield conditions is a self-renewing resource.

No accurate estimate of sustainable yield for the Sparta aquifer in Union County, Arkansas, has previously been determined. Options for utilizing alternative sources of water to alleviate overdraft (removal of water at a rate greater than can be sustained indefinitely) from the Sparta aquifer and ensure that the aquifer can continue to provide abundant water of excellent quality for the future are being evaluated by water managers in Union County. Sustainable yield is a critical element in identifying and designing viable water supply alternatives. With sustainable yield defined (and a clear understanding of the criteria under which that yield is sustainable) and a knowledge of total water demand in an area, any unmet demand-water that must be supplied from alternative sources - can be calculated by taking the difference between "total demand" and "sustainable yield." The ground-water flow model of the Sparta aquifer offers a tool capable of determining sustainable yield using an iterative approach (Fitzpatrick and others, 1990; McWreath and others, 1991; Kilpatrick, 1992; Hays and others, 1998).

The U.S. Geological Survey (USGS) in cooperation with the ASWCC, conducted a study within the framework of the ongoing Sparta aquifer modeling project (a long-term effort maintaining and using the Sparta model to provide information needed for management of the aquifer) to determine and document sustainable yield and to provide aquifer-yield information needed to determine unmet demand for the Sparta aquifer in Union County. Study results will provide water managers in Arkansas with information needed to develop water-management strategies. The study is consistent with the USGS mission in Arkansas in that the understanding of the Sparta aquifer in southeastern Arkansas has been enhanced and scientific information on the aquifer has been provided to assist water mangers. 


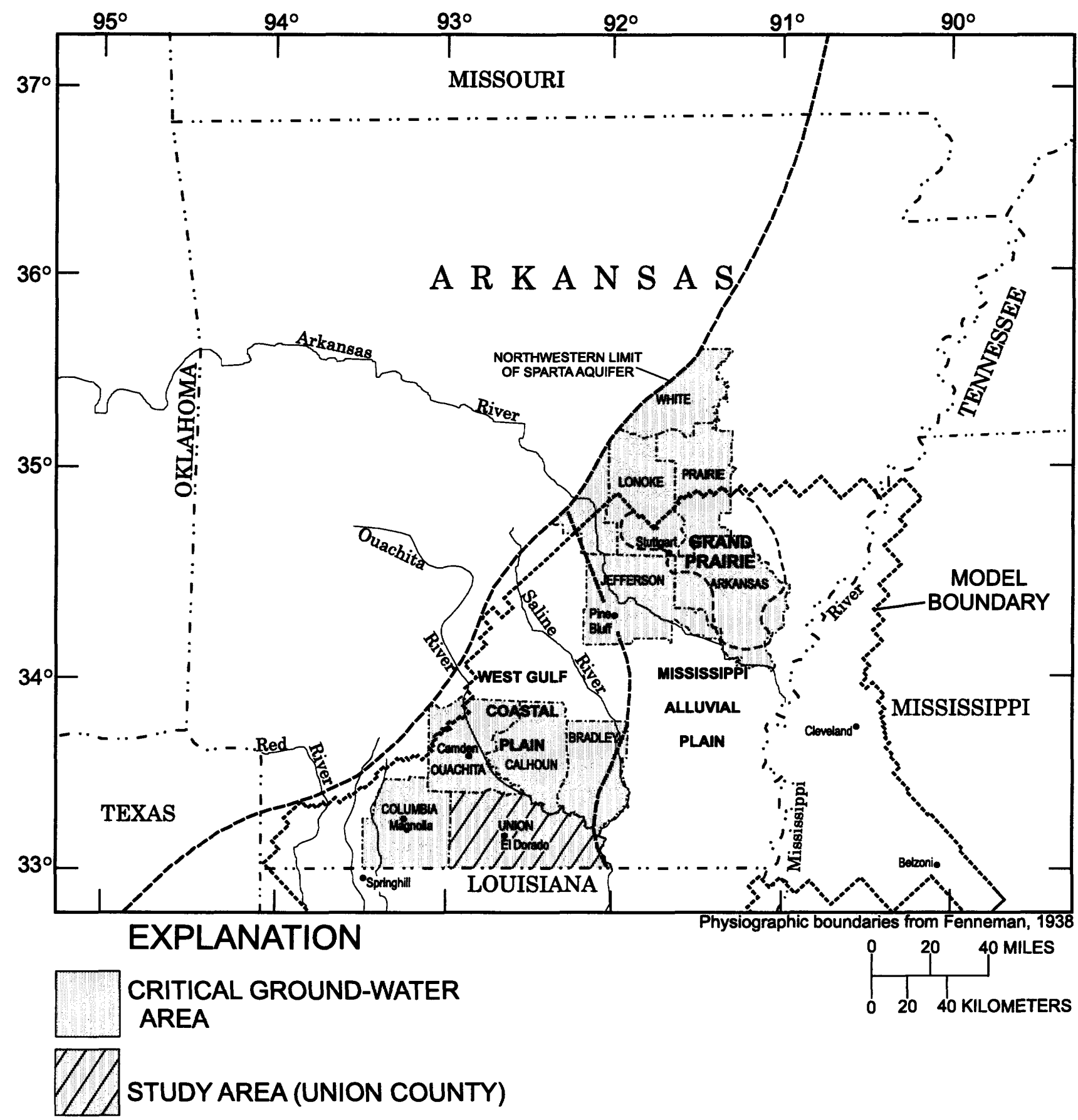

Figure 1. Location of study and model areas. 
The purpose of this report is to present an estimation of sustainable yield for Union County. This report details results of the study specific to Union County sustainable-yield estimation and provides minimal description of the ground-water Sparta flow model, which was previously developed and applied (Fitzpatrick and others, 1990; Hays and others, 1998).

\section{Study Area Description}

The study focuses on Union County in central southern Arkansas. The county comprises approximately 1,055 square miles $\left(\mathrm{mi}^{2}\right)$ in total area and has a population of approximately 47,000 (1990 estimate) (fig. 1). The study area lies almost entirely within the West Gulf Coastal Plain section of the Coastal Plain Physiographic Province (Fenneman, 1938). In Union County, land-surface altitudes range from about 80 feet ( $\mathrm{ft}$ ) above sea level ${ }^{1}$ along the Ouachita River to more than $300 \mathrm{ft}$ in the southwestern part of the county; topography is predominated by low-relief rolling hills and lowland areas. Surficial geology is predominated by the unconsolidated clastic sediments of the Tertiary Claiborne Group with more minor exposures of Quaternary Alluvium deposits proximal to local streams. Geological structure in the area is characterized by abundant normal and growth faults with the occurrence of fault-associated folding; otherwise strata in the area are relatively flat lying. The principal surface-water drainages in Union County are the Ouachita River, Smackover Creek, Three Creeks Bayou, Little Cornie Bayou, Lapile Creek and Bayou Loutre. The major surface-water bodies present in the county are Lakes Felsenthal and Calion; a total of $17 \mathrm{mi}^{2}$ of land area is inundated in the county. Mean annual precipitation is approximately 50 inches (Freiwald, 1985). Land use in the area predominantly comprises agriculture, silviculture, forest, wetland, urban, commercial, and industrial uses; land-use activities have a strong affect on water resource use patterns.

Water use from the Sparta aquifer in the study area reflects predominant land uses; ground water is intensively used for municipal supply, agriculture, and manufacturing of forest products, chemicals, and other industrial products. For data reported to ASWCC in

\footnotetext{
${ }^{1}$ In this report, sea level refers to National Geodetic Vertical Datum of 1929 - a geodetic datum derived from a general adjustment of the first-order level nets of the United States and Canada, formerly called Sea Level Datum of 1929.
}

1997, approximately 50 facilities in the county reported water use totaling about 2.2 million cubic feet per day $\left(\mathrm{ft}^{3} / \mathrm{d}\right)$. Based on quality control work and responses tendered by major water uses (Hays and others, 1998), this figure was increased to 2.8 million $\mathrm{ft}^{3} / \mathrm{d}$ for application in the model. Of the reported total, 56 percent is used for public supply, 2 percent is used for singledwelling domiciles, 40 percent is used for industry, and 2 percent is used for agriculture.

\section{Previous Studies}

In 1985, the USGS, in cooperation with the ASWCC and the Louisiana Department of Transportation and Development (LaDOTD), began a study of the hydrogeologic characteristics of the Sparta aquifer and the regional effects of increased pumpage on water levels in the aquifer. The primary product of the study was a digital model of ground-water flow in the Sparta aquifer (Fitzpatrick and others, 1990; McWreath and others, 1991), referred to here as the "Sparta model." Model construction, calibration , and first application are fully described in Fitzpatrick and others (1990) and McWreath and others (1991). These reports define the initial goals of the model and describe model testing and simulation results for the pumping scenarios posed. Detailed discussion of the history of Sparta aquifer water use, model area hydrogeologic setting, and a description of the aquifer also are included in the two reports and are not repeated here. In 1991, the model was verified (Kilpatrick, 1992) by the USGS in cooperation with the ASWCC; selected scenarios of future ground-water withdrawals in Union County, Arkansas, were simulated. The model was reverified with updated pumpage and potentiometric data in 1997, and various pumping scenarios were simulated (Hays and others, 1998). 


\section{Ground-Water Flow Model Description}

The computer code used by Fitzpatrick and others (1990) and McWreath and others (1991) for development of the Sparta model was the modular finitedifference ground-water flow model (MODFLOW) developed by McDonald and Harbaugh (1988). MODFLOW simulates flow in three dimensions using a block-centered, finite-difference equation approach to the solution of the partial-differential equation for flow. Details of model development, construction, and calibration are presented in Fitzpatrick and others (1990) and McWreath and others (1991). Details on pumpage data updating, assimilation and input, model reverification and error analysis are given in Kilpatrick (1992) and Hays and others (1998). For this study, as for the modeling work described in Hays and others (1998), the Sparta model was converted to run in MODFLOWARC, a MODFLOW pre- and post-processor that allows interface with a geographical information system (Orzol and McGrath, 1992). The model was re-run after conversion (Hays and others, 1998) to ensure that functionality and output were unchanged from originally reported results.

For the current sustainable-yield modeling, described in this report, no basic model parameters, or calibration parameters, were changed, and no changes in input that would violate model assumptions were applied. Study objectives were achieved by varying of well pumpage stress in a discrete area.

\section{APPROACH}

The sustainable yield of the aquifer was calculated by targeting a specified minimum acceptable water level within Union County and varying Union County pumpage within the model to achieve the target water level. A specific category of sustainable yieldstabilization yield, reflecting the amount of water that the aquifer can provide while maintaining current water levels - also was determined using the same approach. In this report, the term "sustainable yield" will refer to the yield that can be sustained without water levels declining below the top of the Sparta Sand, and "stabilization yield" will refer to the yield that can be sustained without having water levels decline below their current position (just above the top of the $\mathrm{El}$ Dorado sand). Sustainable and stabilization yields were estimated for each of two pumping conditions outside of the county: One with simulated future pumpage outside of Union County accelerating at the rate of increase observed from 1985-1997 (table 1), and a second with future pumpage outside of Union County accelerating at twice the rate of increase observed from 1985-1997 (table 1).

To provide information on aquifer conditions if the rate of pumpage from the Sparta aquifer accelerates within Union County, a simulation was conducted representing a scenario in which the current (1985-1997) rate of increase in pumpage in the county was doubled (table 1). This scenario represents the potential for a large increase in community and industrial growth and tests the viability of relying exclusively upon the Sparta aquifer to supply water needs associated with such growth.

Table 1. Union County sustainable-yield, stabilization-yield, and doubled-pumpage scenarios

\section{Sustainable yield}

(1) Pumpage outside of Union County increasing at 1985-1997 rate

(2) Pumpage outside of Union County increasing at double the 1985-1997 rate

Stabilization yield

(3) Pumpage outside of Union County increasing at 1985-1997 rate

(4) Pumpage outside of Union County increasing at double the 1985-1997 rate

\section{Doubled pumpage}

(5) Current (1985-1997) rate of increase of pumpage in Union County is doubled 
Sustainable yield and stabilization yield refer to the rate at which water may be pumped out of the aquifer while maintaining the target water level, whether that level be the top of the Sparta Sand (for sustainable yield) or the top of the El Dorado sand (for stabilization yield). Under steady-state conditions, there is no contribution from aquifer storage to water removed by pumping, and the amount of water moving into the aquifer is equal to the amount being removed. Under transient conditions, a time period in which to achieve the target water level is selected ( 30 years in this case), and pumpage is varied to achieve the target at the end of the simulation; water contributed from storage helps to meet the target water level under the given pumping conditions if the time period selected is less than that required to achieve steady-state conditions.

Selection of the minimum target water level for sustainable-yield estimation was an important criterion for the modeling effort. Arkansas law has established that an area served by a confined aquifer be designated as a CGWA if 1) water levels have dropped below the top of the geologic formation containing the aquifer or 2) water levels are dropping more than $1 \mathrm{ft} / \mathrm{yr}$. The Sparta aquifer in Union, Columbia, Ouachita, Calhoun, and Bradley Counties meets CGWA designation criteria, and these counties were designated as the State's first CGWA in 1996. The CGWA law was developed by the State using available hydrologic data and applying hydrologic principles; when water levels drop below the top of a confined aquifer, the aquifer becomes unconfined in that area and dewatering ensues. In addition, as water levels drop below the top of the aquifer, offset of lithostatic pressure by hydraulic pressure head reaches a minimum and buoyant support of the aquifer by water is lost. These conditions result in compaction of the aquifer matrix and can damage the aquifer by decreasing hydraulic conductivity. Therefore, maintaining water levels above the top of a confined aquifer protects the integrity of the aquifer for long-term use. The top of the uppermost producing sands defining the Sparta aquifer does not necessarily coincide with the top of the Sparta Sand (the gross geologic formation); the top of the uppermost producing sand may be interpreted as the top of the aquifer. Vertical position and areal extent of producing sands within the Sparta Sand vary considerably across the region. By defining the top of the Sparta Sand as a minimum water-level criterion for CGWA designation, regulators have avoided adapting the law from one area of the State to another to address facies changes and extent of individual sand units and provide protection for more minor sand units that may be above primary producing sands (fig. 2).

In keeping with the State CGWA designation criteria and the desire of water managers in Union County to improve aquifer conditions and bring the area out of the CGWA designation, the approximate altitude of the top of the Sparta Sand in central Union County (50 ft below sea level) was used as the minimum water level target for estimation of sustainable yield in the county. The top of the primary producing sand unit (the $\mathrm{El}$ Dorado sand, with an approximate altitude of about $300 \mathrm{ft}$ below sea level in central Union County) was used as the minimum water-level target for estimating stabilization yield in the county; this estimation was conducted to provide information for short-term management. Minimum water levels in the county are very near the top of this unit at this time, and as such this yield is termed the stabilization yield, representing the amount of water that the aquifer can provide while maintaining current water levels.

Sustainable and stabilization yields of the aquifer were calculated by targeting the specified minimum desired water level within Union County and varying simulated pumpage within Union County to achieve that water level. The final solution was calculated iteratively; pumpage was input for each of a series of model runs, a resultant minimum water level was determined, and if the resultant was not the target water level, Union County pumpage was adjusted in a succeeding run to move closer to the target water level. Changes to pumpage in Union County for each iteration were applied as uniform percentage increases or decreases in pumping cells across the county. For example, in a solution whereby 28 percent of current pumpage in the county was used and the resulting model-derived water levels were equal to the target water level, then 28 percent of current pumpage is the aquifer yield estimated to result in the target water level. Basically, pumpage needed to be decreased to achieve the target level.

Steady-state and transient (achieving the target water level at 30 years) solutions were generated for sustainable and stabilization yields under both pumping conditions. The steady-state solutions calculate flows and water levels resulting from applied pumping 


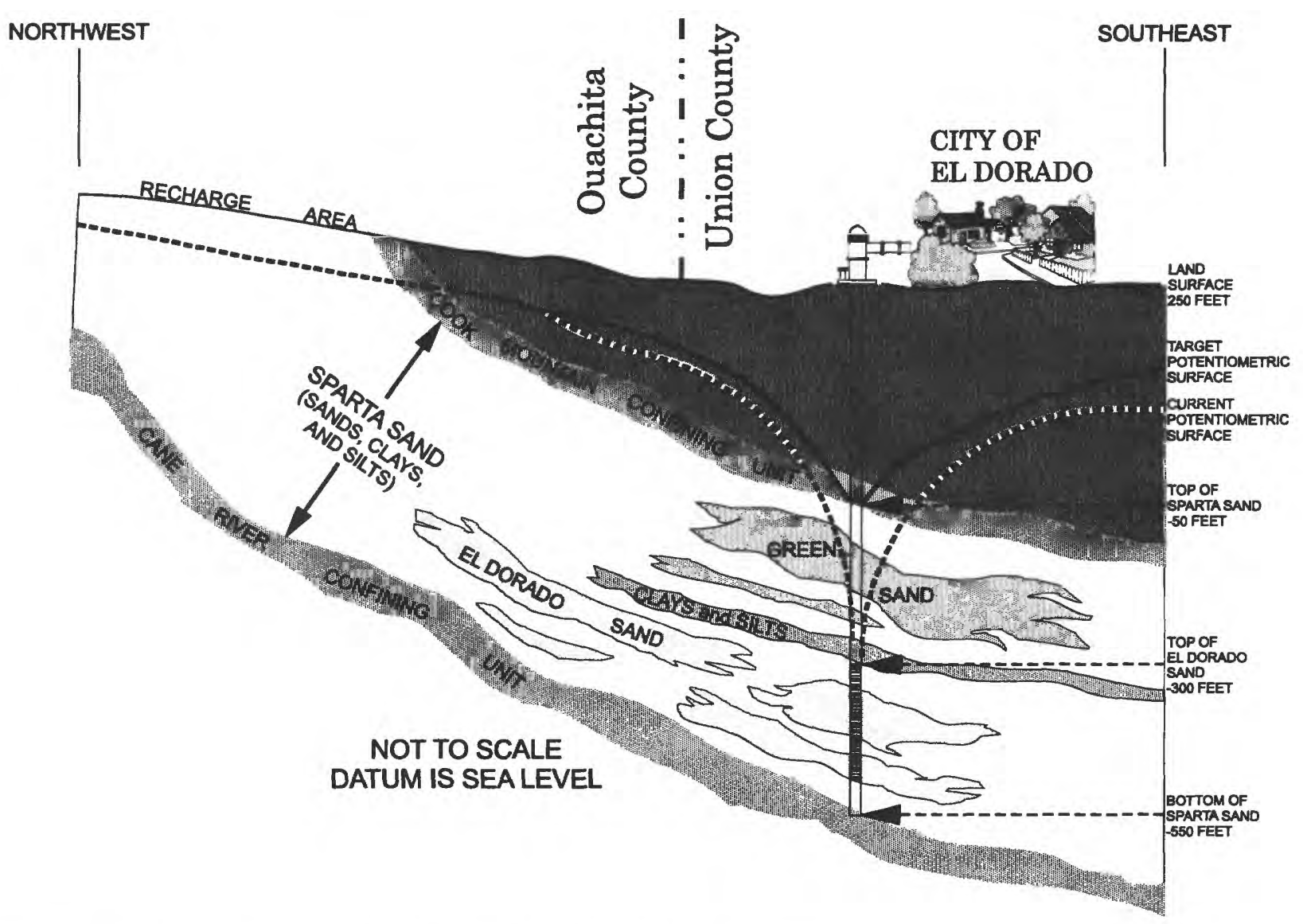

Figure 2. Diagrammatic section of the Sparta aquifer in the Union County area.

stress without any input into the system from storage and provide the most definitive estimation of sustainable yield. The transient solutions are valuable for characterizing contribution from storage through time and showing the amount of time in which the aquifer will respond to decreased pumping stress. Thus, two separate solutions were generated for each pumping condition outside of Union County. More than 600 model runs were conducted in the iterative approach to achieve the target water levels for the steady-state and transient solutions for the sustainable- and stabilization-yield pumping scenarios. The iterations were continued at 1 percent adjustment increments for each scenario until the percentage value that resulted in a minimum water level closest to the target was obtained. All minimum water levels were within $2 \mathrm{ft}$ of the target water level.

\section{SUSTAINABLE- AND STABILIZATION- YIELD SIMULATION RESULTS}

Sustainable-yield simulations were run for steady-state and transient conditions using two scenarios (table 1). Steady-state solutions were derived to provide the best long-term estimation of sustainable yield; the steady-state solution is important because that solution provides the Union County pumpage estimate (presented as a percentage of 1997 pumpage in this report) that would maintain water levels at the top of the Sparta Sand indefinitely and enable the county to address the CGWA criteria. Transient solutions were derived to provide information on the response of the aquifer over time; the transient solution provides the county pumpage estimate that would achieve water levels at the top of the Sparta Sand after 30 years, but not necessarily for an indefinite period of time. Under scenario 1, pumpage from the Sparta aquifer outside of Union County was increased at the 1985-1997 rate of 
increase for 1998-2027 in the transient simulation and was set at the projected 2027 maximum in the steadystate simulation (table 2). The trends derived from 1985-1997 data were determined separately for each individual county and applied on a county-by-county basis to the 1998-2027 simulation period. Under scenario 2, pumpage from the Sparta aquifer outside of Union County was increased at double the 1985-1997 rate of increase for 1998-2027 in the transient simulation and was set at the projected 2027 double-rate maximum in the steady-state simulation.

Table 2. Reported and projected pumping estimates for Union County and the model area outside of Union County $\left[\mathrm{ft}^{3} / \mathrm{d}\right.$, cubic foot per day]

\begin{tabular}{lcl}
\hline & Union County & Outside Union County \\
\hline 1997 & 2.8 million $\mathrm{ft}^{3} / \mathrm{d}$ & 30.3 million $\mathrm{ft}^{3} / \mathrm{d}$ \\
2027 & 3.7 million $\mathrm{ft}^{3} / \mathrm{d}$ & 49.1 million $\mathrm{ft}^{3} / \mathrm{d}$ \\
$\begin{array}{l}\text { (projected) } \\
\begin{array}{l}2027 \\
\text { (projected rate } \mathrm{x} \text { 2) }\end{array}\end{array}$ & 4.8 million $\mathrm{ft}^{3} / \mathrm{d}$ & 100.1 million $\mathrm{ft}^{3} / \mathrm{d}$ \\
\hline
\end{tabular}

Stabilization yield simulations also were run for both steady-state and transient conditions using two scenarios (table 1, scenarios 3 and 4). Just as for the sustainable-yield target, the steady-state and transient solutions provide long-term and 30-year results, respectively, for the stabilization target. Under scenario 3, pumpage from the Sparta aquifer outside of Union County was increased at the 1985-1997 rate of increase for 1998-2027 in the transient simulation and was set at the projected 2027 maximum in the steady-state simulation (table 2). Under scenario 4, pumpage from the Sparta aquifer outside of Union County was increased at double the 1985-1997 rate of increase for 1998-2027 in the transient simulation and was set at the projected 2027 double-rate maximum in the steady state simulation.

\section{Sustainable-Yield Simulation Results}

For simulation 1a, a steady state simulation in which future pumpage outside of Union County is assumed to increase at the rate observed from 1985 1997, withdrawals from the Sparta aquifer in Union County must be reduced to 28 percent of 1997 values (table 3 ) to achieve sustainable yield and maintain water levels at the top of the Sparta Sand ( $50 \mathrm{ft}$ below sea level). Pumpage in this simulation was assigned as the rate attained after 30 years of assumed increases. Results of simulation 1a define a very large current unmet demand and represent a substantial reduction in the county's current dependence upon the aquifer (fig. 3). Unmet demand refers to the amount of water that is required for various uses that cannot be provided by the aquifer on an indefinite basis. A comparison of the simulated potentiometric surface generated from results of simulation 1a (fig. 4) with the potentiometric surface simulated for a scenario completed for a previous study (Hays and others, 1998) in which all pumpage (including Union County) continues to increase at the 19851997 rate for 30 years (fig. 5) underscores the magnitude of the unmet demand and the effect on the aquifer. To achieve sustainable yield, the unmet demand defined by the model simulation and any future increases in demand resulting from growth in the county would require measures such as reducing water use through conservation and the use of alternative sources. Water levels in central Union County (near El Dorado) could be expected to rebound to near the top of the Sparta Sand quite rapidly with reduction of pumpage. Because the Sparta aquifer is confined in Union County, changes in stress are communicated rapidly across the aquifer, and water levels will respond quickly.

Whereas the result of simulation 1a provides the appropriate sustainable yield for long-term management of the aquifer (28 percent of 1997 pumpage rates), a transient solution - simulation $\mathrm{lb}$ - set up to achieve a specific target water level at a specific point in time provides information on the volumetric flows to and from the aquifer through time. This information facilitates improved understanding of aquifer behavior and temporal response. We expect that the resultant in a transient solution would be greater than that for the steady-state solution for a given scenario in which all other factors remain constant, because water can still be removed from storage in the transient solution. Thus, the allowable pumpage for the transient solution would be greater than the sustainable yield pumpage for steady-state solution although achieving the same water-level target.

To evaluate aquifer response, transient simulation (simulation $1 \mathrm{~b}$ ) results, in which pumpage outside of Union County was increased over six 5-year stress periods, indicate that pumpage from the aquifer in 


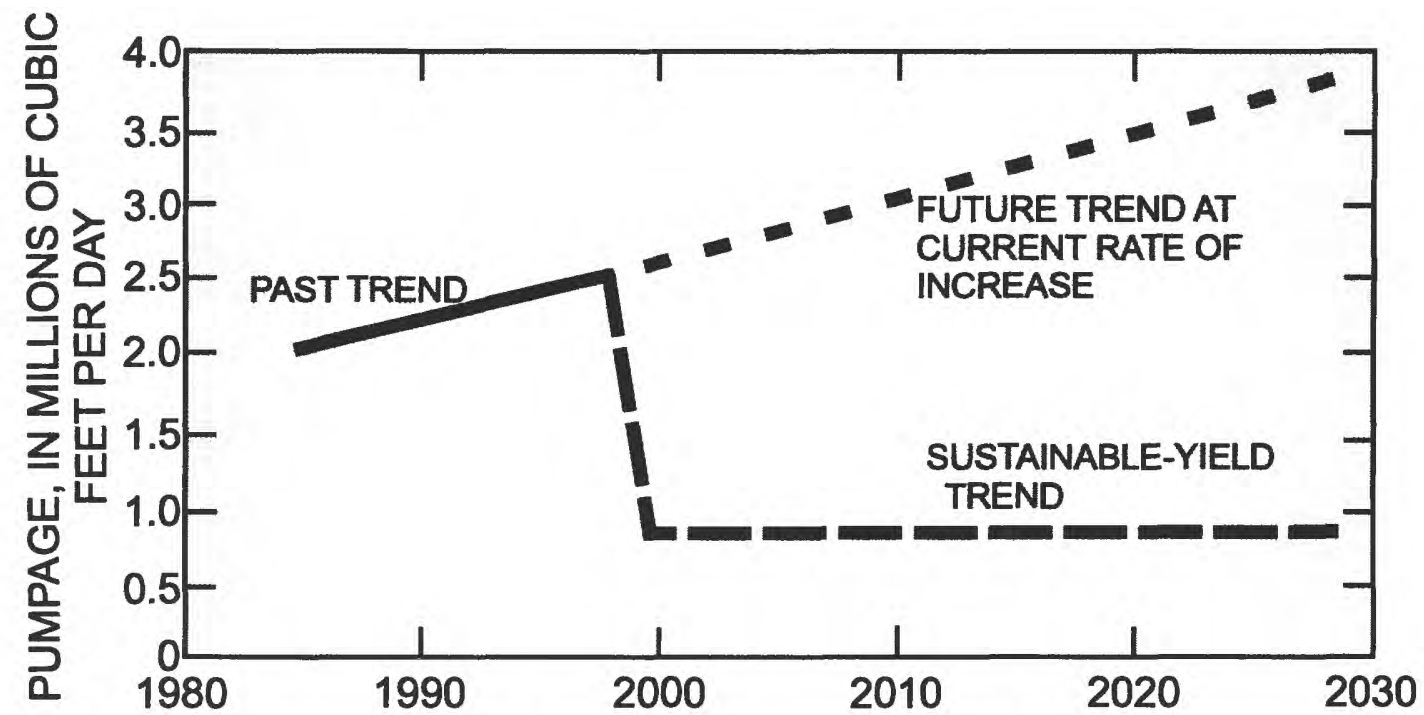

Figure 3. Observed and predicted trend for pumpage from the Sparta aquifer in Union County, Arkansas, 1985-2027; sustainable-yield trend shows how pumpage must change to achieve sustainable yield.

Union County should be reduced to 32 percent of current values (table 3 ) to maintain water levels at the top of the Sparta Sand and show that most of the targeted rebound occurs within 5 years of decreasing withdrawals. The simulation potentiometric surface (after 30 years) is similar to that shown in figure 4 for simulation la. Volumetric budget components are shown in figure 6; simulated inflows to and outflows from the aquifer-pumpage removed by wells, net recharge added by precipitation, water moving from and to rivers, water moving from and into the overlying Cockfield aquifer, boundary flow, and changes in water stored in the aquifer-are depicted.
Simulation $2 \mathrm{a}$ is a steady state simulation in which future pumpage outside of Union County is assumed to increase at double the rate observed from 1985-1997. Pumpage in this simulation was assigned as the rate attained after 30 years of projected increases. Under this scenario, withdrawals from the Sparta aquifer in Union County must be reduced to 25 percent of 1997 values (table 3 ) to achieve sustainable yield and maintain water levels at the top of the Sparta Sand (50 $\mathrm{ft}$ below sea level). Again, there is a large unmet demand. However, only an additional 3 percent reduction in Union County pumpage-as compared to the

Table 3. Sustainable-yield results for the top of the Sparta Sand water-level target for current rate of increase and double current rate of increase pumpage conditions

\begin{tabular}{lc}
\hline \multicolumn{1}{c}{ Scenario } & $\begin{array}{c}\text { Union County pumpage } \\
\text { (percent of 1997 rate) }\end{array}$ \\
\hline $\begin{array}{l}\text { Pumpage outside of Union County set at projected 2027 value for steady-state } \\
\text { solution, and increasing at the 1985-1997 rate of increase for 1998-2027 in tran- } \\
\text { sient solution }\end{array}$ & 28 percent \\
Simulation 1a, Steady state & 32 percent \\
Simulation 1b, Transient & \\
Pumpage outside of Union County set at projected 2027 double-rate maximum \\
value for steady-state solution, and increasing at double the 1985-1997 rate for \\
$\begin{array}{l}\text { 1998-2027 for transient solution } \\
\text { Simulation 2a, Steady state }\end{array}$ \\
Simulation 2b, Transient
\end{tabular}




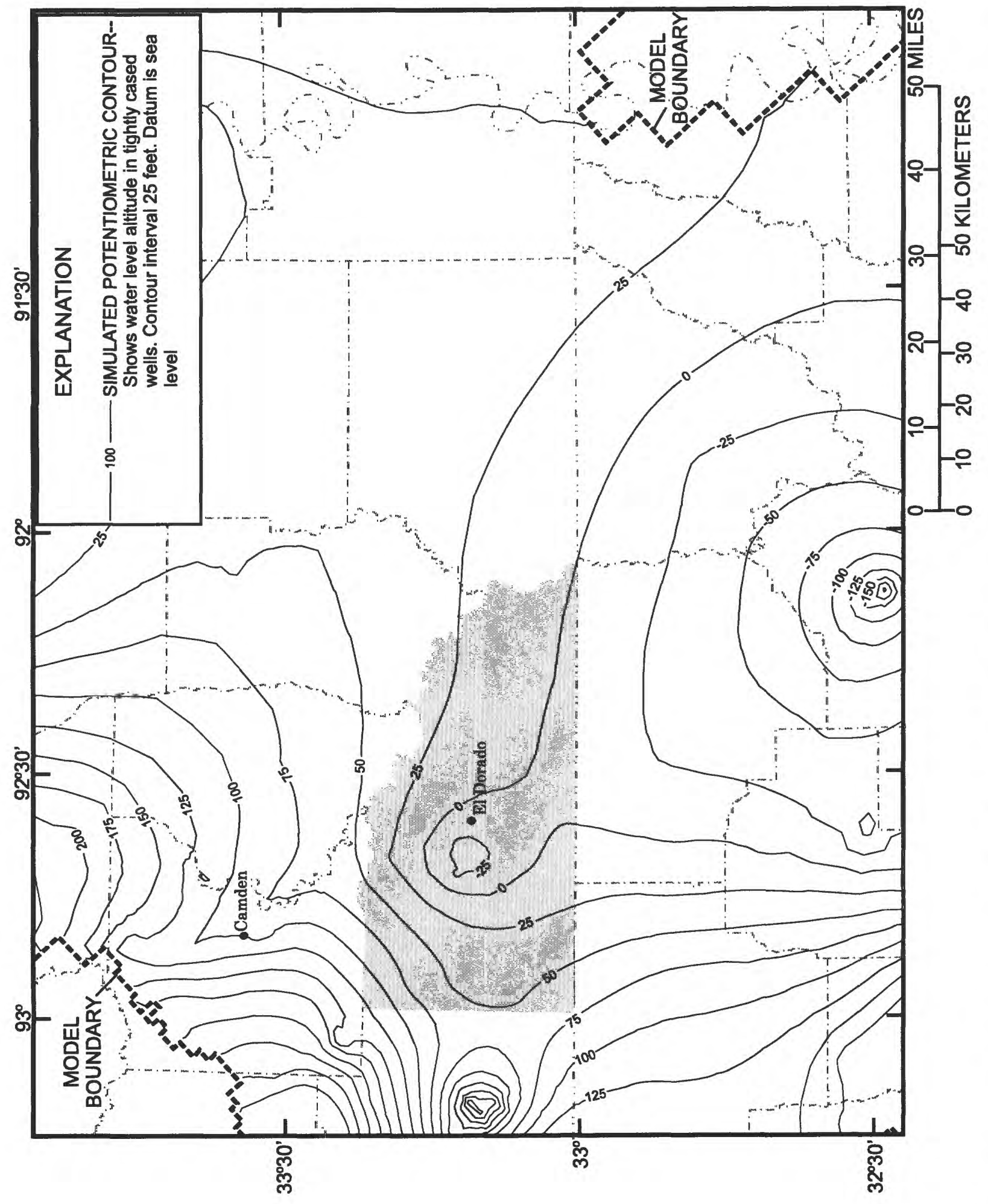

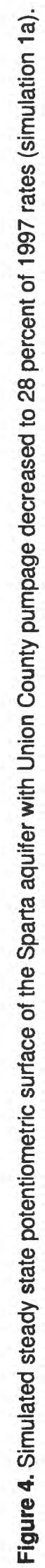




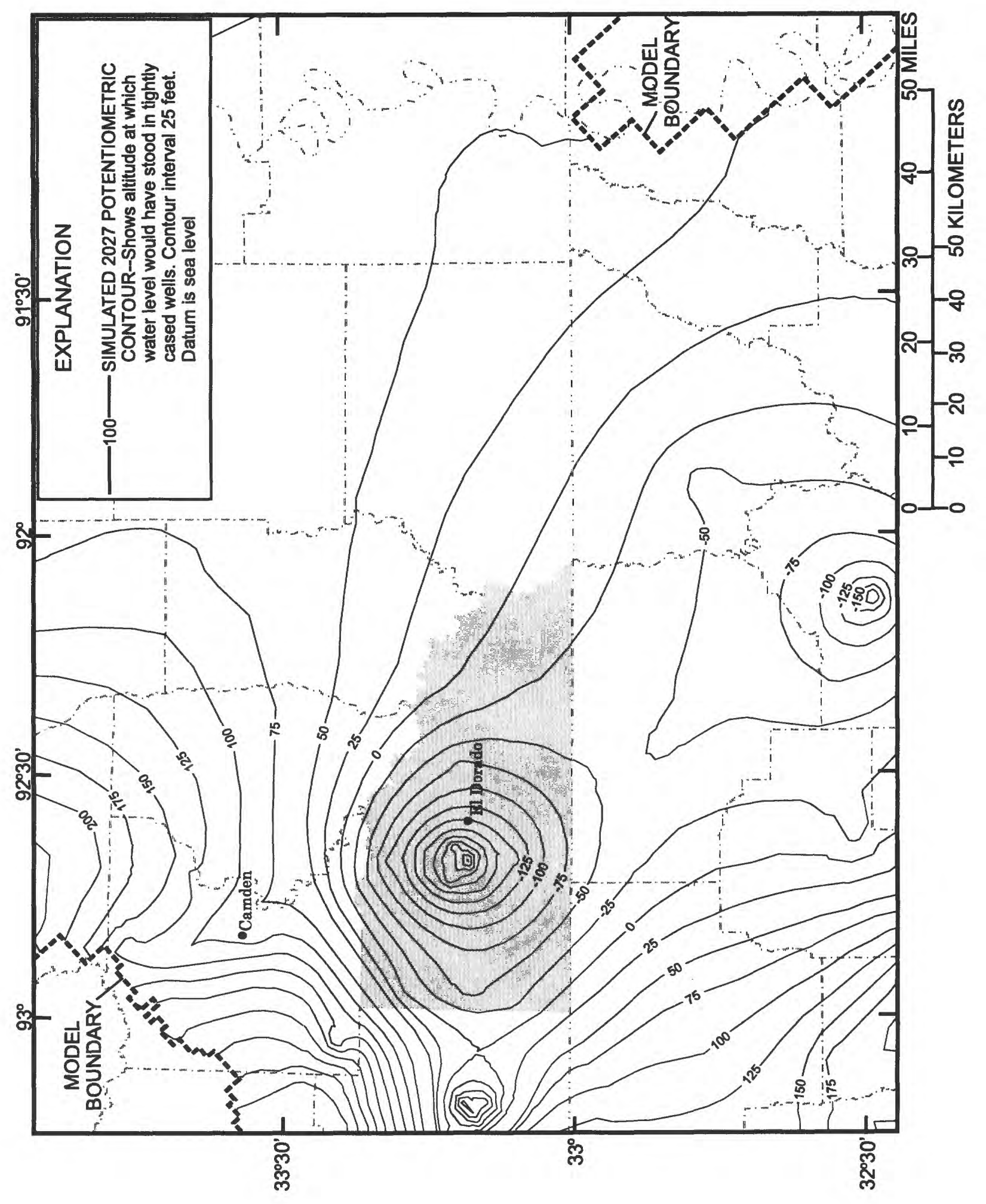

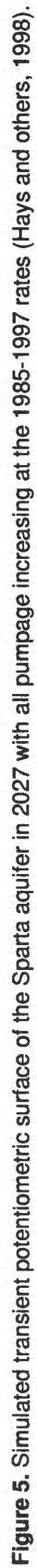




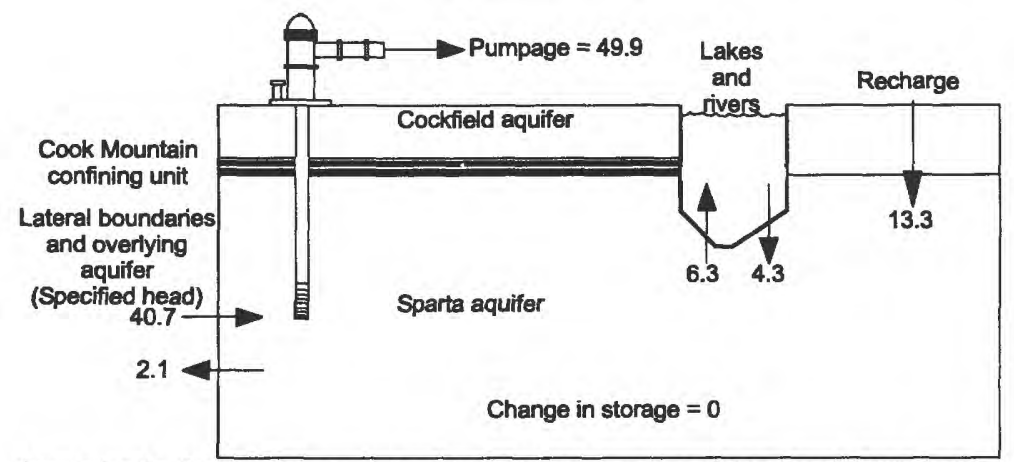

Simulation 1a, Steady state simulation, Union County pumpage at 28 percent of 1997 value. Pumpage outside of Union County assigned as the rate attained after 30 years at 1985-

1997 rate of increase

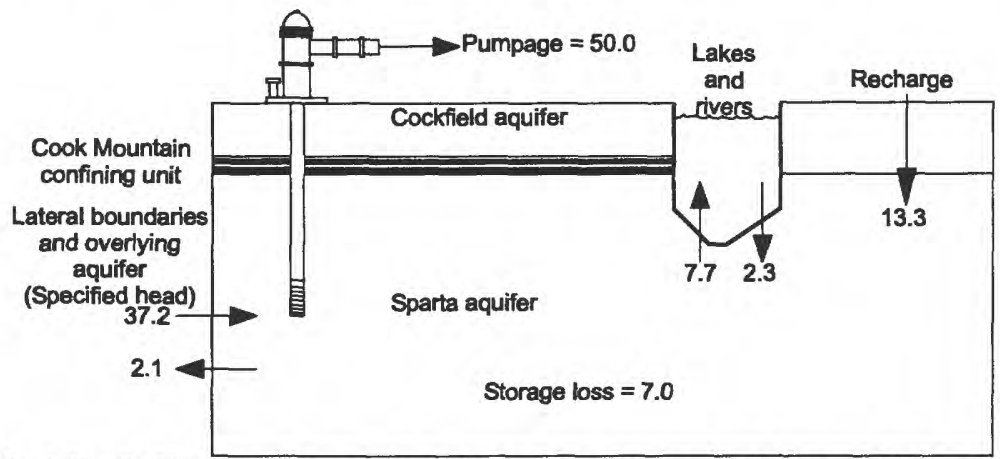

Simulation 1b, 30-year transient simulation, Union County pumpage at 32 percent of 1997 value. Pumpage outside of Union County increasing at 1985-1997 rate of increase

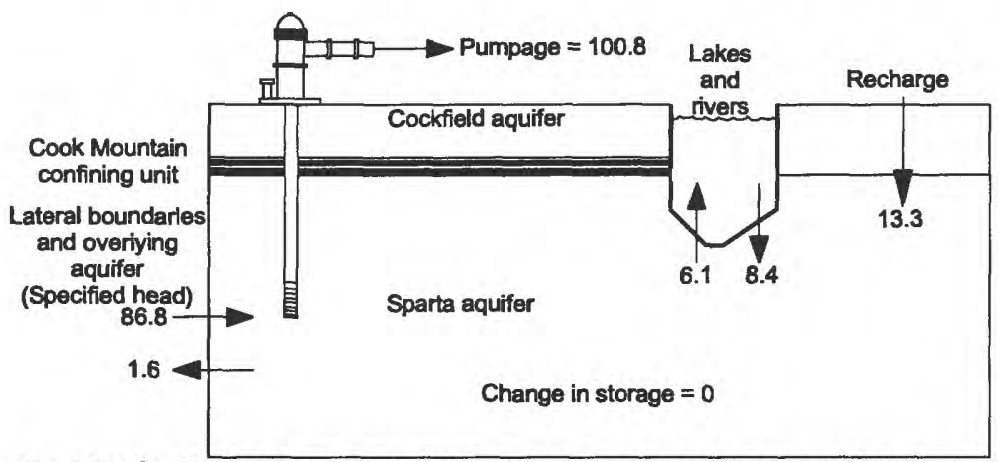

Simulation 2a, Steady state simulation, Union County pumpage at 25 percent of 1997 value. Pumpage outside of Unlon County assigned as the rate attained after 30 years at double the 1985-1997 rate of increase

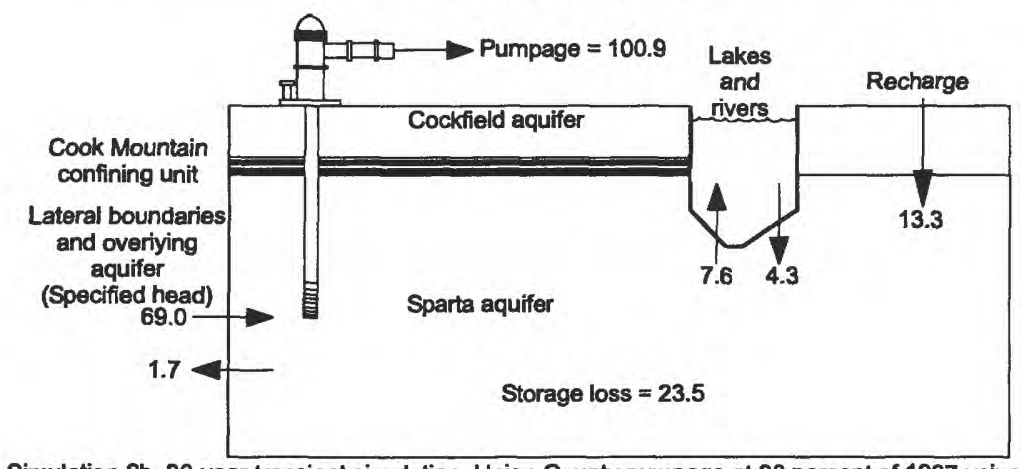

Simulation 2b, 30-year transient simulation. Union County pumpage at 30 percent of 1997 value.

Pumpage outside of Union County increasing at double the 1985-1997 rate of increase

Figure 6. Volumetric budget components (entire model) for sustainable-yield scenarios. 
1985-1997 increase rate scenario (simulation 1a)-is required to offset the greater rate of pumpage in surrounding counties. This finding corroborates area pumpage data showing that withdrawals in Union County constitute a predominant portion of total pumpage in the area. The transient solution for this scenario - in which water may be removed from storage in the aquifer-shows that reducing withdrawals to 30 percent of current values would achieve the top-ofSparta Sand water-level target.

\section{Stabilization-Yield Results}

Simulation 3a is a steady state simulation in which future pumpage outside of Union County is assumed to increase at the rate observed from 1985 1997; pumpage in this simulation was assigned as the rate attained after 30 years of projected increases. Simulation 3a shows that withdrawals from the Sparta aquifer in Union County must be reduced to 91 percent of 1997 values (table 4) to stabilize water levels at the top of the El Dorado sand ( $300 \mathrm{ft}$ below sea level; fig. 7) and that the 1997 rate of withdrawal in the county is considerably greater than the rate needed to halt the rapid decline in water levels. If withdrawals from the aquifer continue to increase, this demand will result in accelerated declines. Whereas the simulation $3 \mathrm{a}$ steady-state model run result provides the appropriate pumpage rate in the county to permanently stabilize water levels at the 1997 level, the transient solution (simulation 3b) - set up to hold the 1997 water level through 2027-provides an additional understanding of aquifer behavior and temporal response. The transient solution for determining stabilization yield-in which water may be removed from storage in the aquifer-shows that reducing withdrawals to 96 percent of 1997 values would achieve the top-of-El Dorado sand water-level target at the 30-year point (table 4).

Simulation $4 \mathrm{a}$ is a steady state simulation in which future pumpage outside of Union County is assumed to increase at double the rate observed from 1985-1997 and was assigned in the model as the rate attained after 30 years of projected increases. Pumpage from the Sparta aquifer in Union County must be reduced to 88 percent of current values (table 4 ) to stabilize water levels at the top of the El Dorado sand (300 $\mathrm{ft}$ below sea level). As compared to the 1985-1997 increased rate simulation (3a), only an additional 3 percent reduction in Union County withdrawals is required to offset withdrawals in surrounding counties. This finding is in agreement with area water-use data showing that withdrawals in Union County constitute the major portion of total pumpage in the area. The transient solution for determining stabilization yield

Table 4. Stabilization-yield results for the top of the El Dorado sand water-level target for current rate of increase and double current rate of increase pumpage conditions

\begin{tabular}{lc}
\hline \multicolumn{1}{c}{ Scenario } & $\begin{array}{c}\text { Union County pumpage } \\
\text { (percent of 1997 rate) }\end{array}$ \\
\hline $\begin{array}{l}\text { Pumpage outside of Union County set at projected } 2027 \text { value for steady-state } \\
\text { solution and increasing at the } 1985-1997 \text { rate of increase for 1998-2027 for } \\
\text { transient solution }\end{array}$ & 91 percent \\
Simulation 3a, Steady state & 96 percent \\
Simulation $3 b$, Transient & \\
$\begin{array}{l}\text { Pumpage outside of Union County set at projected } 2027 \text { double-rate maximum } \\
\text { value for steady-state solution and increasing at double the } 1985-1997 \text { rate for } \\
1998-2027 \text { for transient solution } \\
\text { Simulation } 4 \mathrm{a}, \text { Steady State } \\
\text { Simulation } 4 \mathrm{~b}, \text { Transient }\end{array}$ & 88 percent \\
\hline
\end{tabular}




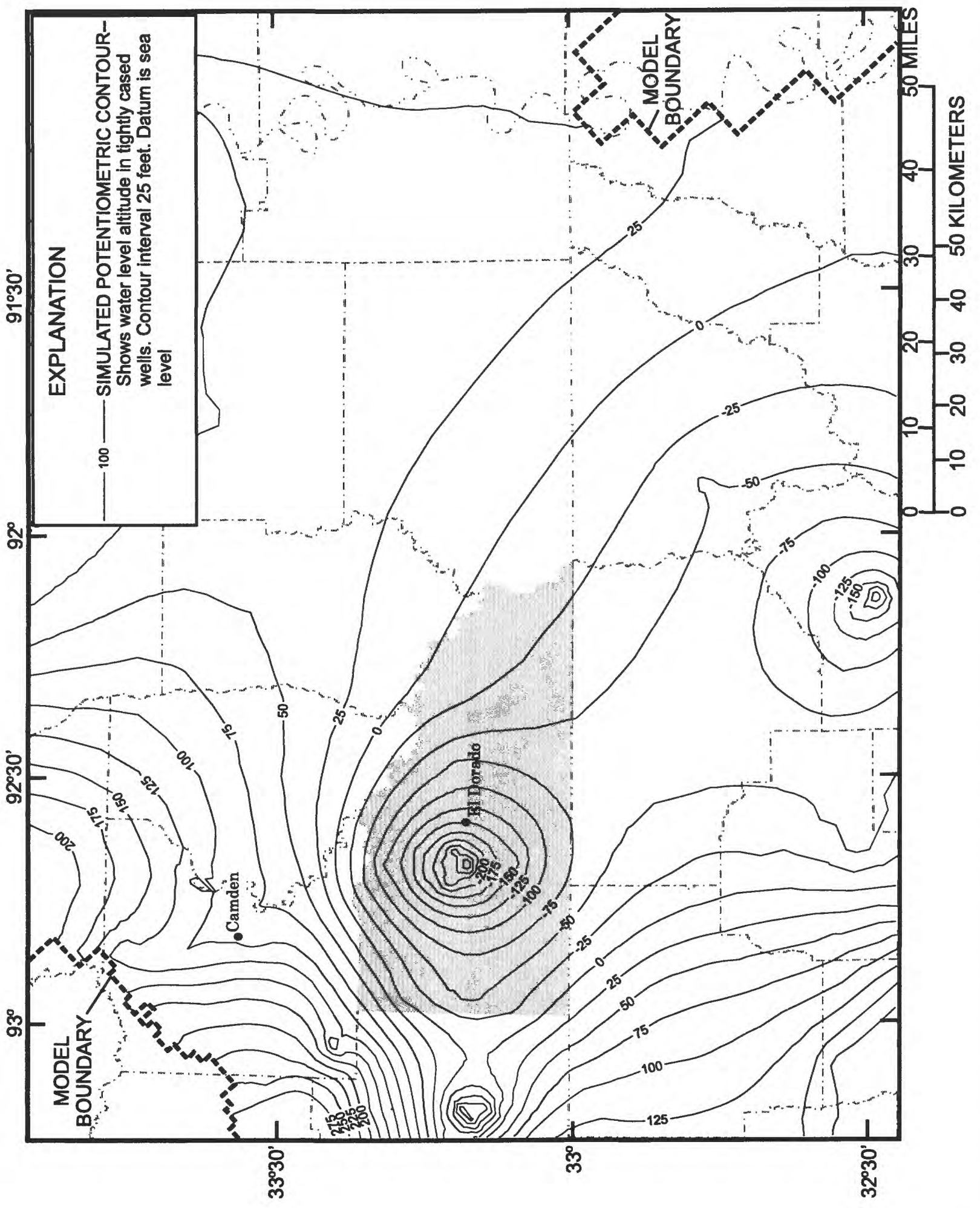

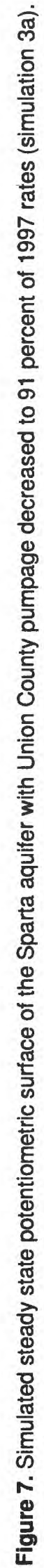


(simulation 4b) - in which water may be removed from storage in the aquifer-shows that reducing withdrawals to 94 percent of current values would achieve the top-of- El Dorado sand water-level target (table 4). Volumetric budget components are shown in figure 8 .

\section{DOUBLED-PUMPAGE RATE SIMULATION RESULTS}

For the scenario in which the rate of increase for Union County pumpage was double the observed 1985-1997 rate, simulation indicates that water levels in central Union County would drop to more than 580 $\mathrm{ft}$ below sea level. Under the extreme, final conditions prevailing in this scenario, the numerical result is inaccurate, although informative, because in the current version of the calibrated model, the model assumes confined conditions are always prevalent irrespective of drawdown. This amount of drawdown would be insupportable by the aquifer; practical constraints of aquifer yield and well yield and transition to locally unconfined conditions would manifest before water levels dropped the amount simulated.

\section{SUMMARY AND CONCLUSIONS}

The basic results of the study provide three primary conclusions: 1) Irrespective of how withdrawals from the Sparta aquifer change (within reasonable limits) outside of Union County, withdrawals within Union County must be reduced to about 25 to 28 percent of 1997 rates to cause water levels to rise to the top of the Sparta Sand, thereby achieving a sustainable yield and addressing CGWA designation criteria.

2) Withdrawals would have to be reduced to about 88 to 91 percent of 1997 rates to stabilize water levels above the top of the El Dorado sand.

3) The yield from the aquifer is not great enough to support a doubling of the rate of increase in pumpage in Union County over the long term.

The Sparta aquifer is a confined aquifer of regional importance that comprises a sequence of unconsolidated sand units that are contained within the Sparta Sand. The aquifer extends across much of eastern and southeastern Arkansas and into adjoining states and is a principle water resource for municipal, industrial, and agricultural uses. Currently, the rate of withdrawal in some areas greatly exceeds the rate of recharge to the aquifer. Large cones of depression are centered beneath the Grand Prairie area and the cities of Pine Bluff and El Dorado in Arkansas - areas included in CGWA designated by the Arkansas Soil and Water Conservation Commission (ASWCC). Results from the regional-scale, digital ground-water flow model for the Sparta aquifer indicate that the aquifer cannot continue to meet growing water-use demands indefinitely and that water levels will drop below the top of the primary producing sand unit in Union County (locally termed the El Dorado sand) by 2008 if current water-use trends continue. Declines of that magnitude will initiate dewatering of the $\mathrm{El}$ Dorado sand.

Options for utilizing alternative sources of water to alleviate overdraft from the Sparta aquifer and ensure that the aquifer can continue to provide abundant water of excellent quality for the future are being evaluated by water managers in Union County. Sustainable yield is a critical element in identifying and designing viable water supply alternatives. With sustainable yield defined and a knowledge of total water demand in an area, any unmet demand can be calculated. The ground-water flow model of the Sparta aquifer was used to estimate sustainable yield using an iterative approach.

The sustainable yield of the aquifer was calculated by targeting a specified minimum acceptable water level within Union County and varying Union County pumpage within the model to achieve the target water level. Selection of the minimum target water level for sustainable-yield estimation was an important criterion for the modeling effort. In keeping with the State CGWA designation criteria and the desire of water managers in Union County to improve aquifer conditions and bring the area out of the CGWA designation, the approximate altitude of the top of the Sparta Sand in central Union County was used as the minimum water level target for estimation of sustainable yield in the county. A specific category of sustainable yield - stabilization yield, reflecting the amount of water that the aquifer can provide while maintaining current water levels - also was determined and provides information for short-term management. The top of the primary producing sand unit (the El Dorado sand) was used as the minimum water-level target for estimating stabilization yield in the county because current minimum water levels in central Union County are near the top of the El Dorado sand. Sustainable and stabilization yields were estimated for each of two pumping conditions outside of the county. 


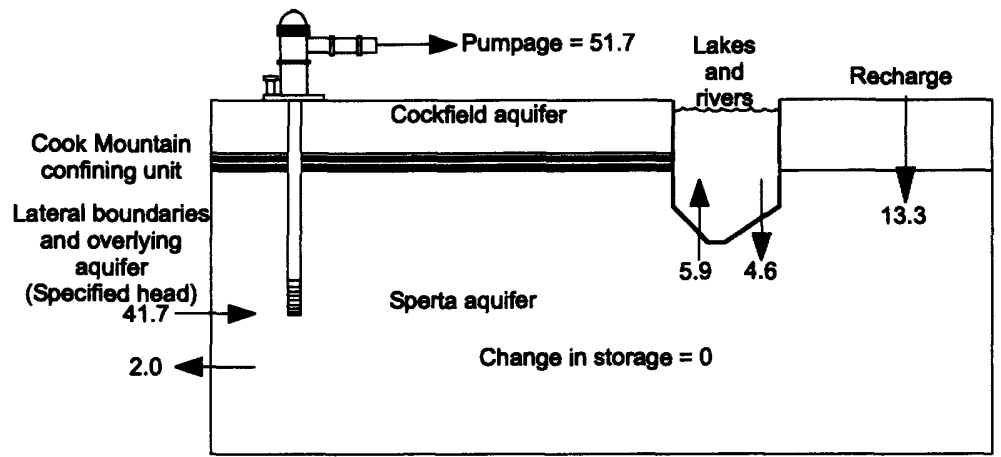

Simulation 3a, Steady state simulation, Union County pumpage at 91 percent of 1997 value. Pumpage outside of Union County assigned as the rate attained after 30 years at 19851997 rate of increase

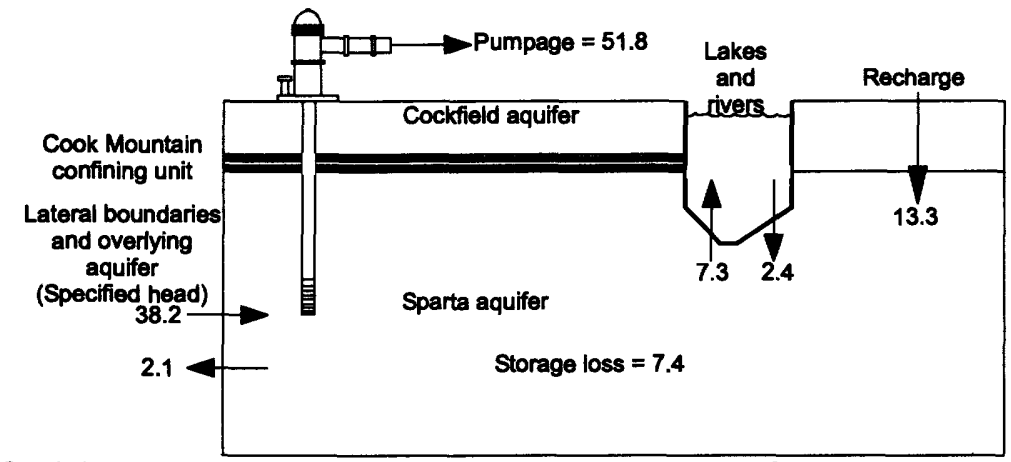

Simulation 3b, 30-year transient simulation, Union County pumpage at 96 percent of 1997 value. Pumpage outside of Union County increasing at 1985-1997 rate of increase

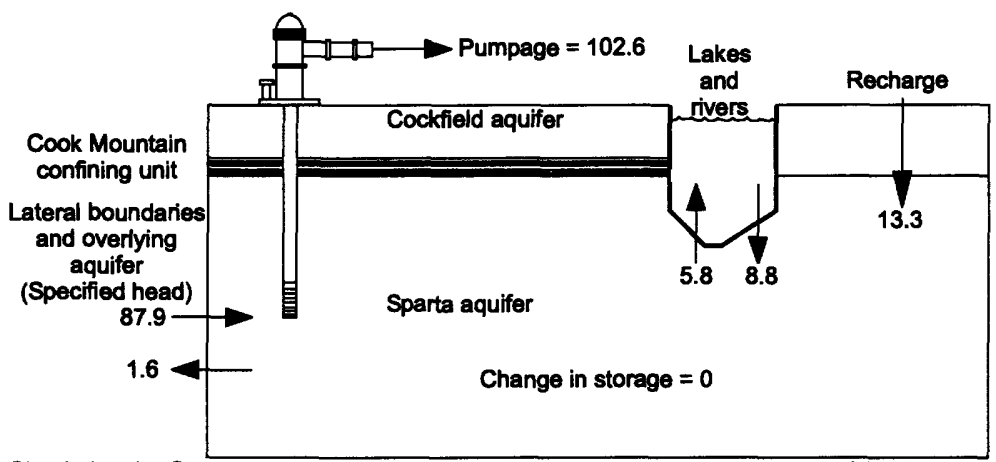

Simulation 4a, Steady state simulation, Union County pumpage at 88 percent of 1997 value. Pumpage outside of Union County assigned as the rate attained after $\mathbf{3 0}$ years at double the 1985-1997 rate of increase

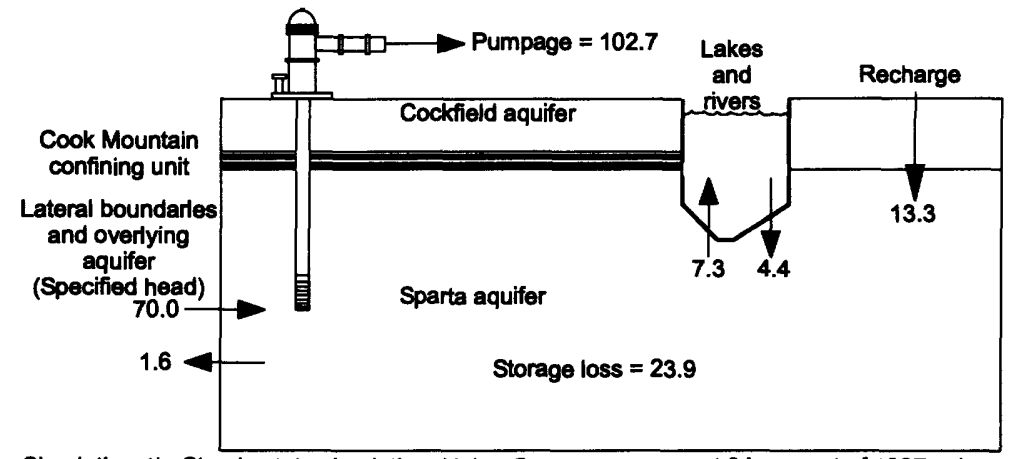

Simulation 4b, Steady state simulation, Union County pumpage at 94 percent of 1997 value. Pumpage outside of Union County increasing at double the 1985-1997 rate of increase

Figure 8. Volumetric budget components (entire model) for stabilization-yield scenarios. 
For the simulation in which future pumpage outside of Union County is assumed to increase at the rate observed from 1985-1997, withdrawals from the Sparta aquifer in Union County must be reduced to 28 percent of 1997 values to achieve sustainable yield and maintain water levels at the top of the Sparta Sand. Results of the simulation define a very large current unmet demand and represent a substantial reduction in the county's current dependence upon the aquifer. To achieve sustainable yield, the unmet demand defined by the model simulation and any future increases in demand resulting from growth in the county would require measures such as reducing water use through conservation and the use of alternative sources.

For the simulation in which future pumpage outside of Union County is assumed to increase at double the rate observed from 1985-1997, withdrawals from the Sparta aquifer in Union County must be reduced to 25 percent of 1997 values to achieve sustainable yield. Only an additional 3 percent reduction in Union County pumpage is required to offset the greater rate of pumpage in surrounding counties as compared to the 1985-1997 increase rate scenario. This finding corroborates area pumpage data showing that withdrawals in Union County constitute a predominant portion of total pumpage in the area.

For the simulation in which future pumpage outside of Union County is assumed to increase at the rate observed from 1985-1997, withdrawals from the Sparta aquifer in Union County must be reduced to 91 percent of 1997 values to stabilize water levels at the top of the El Dorado sand. This result shows that 1997 rate of withdrawal in the county is considerably greater than the rate needed to halt the rapid decline in water levels. If withdrawals from the aquifer continue to increase, this demand will result in accelerated declines.

For the simulation in which future pumpage outside of Union County is assumed to increase at double the rate observed from 1985-1997, pumpage from the Sparta aquifer in Union County must be reduced to 88 percent of current values to stabilize water levels at the top of the El Dorado sand.

\section{REFERENCES}

Baker, R.C., Hewitt, F.A., and Billingsley, G.A., 1948, Ground-Water Resources of the El Dorado area, Union County, Arkansas: University of Arkansas Research Series No. 14, 39 p.
Fenneman, N.M., 1938, Physiography of eastern United States: New York, McGraw-Hill Book Co., Inc., 689 p. Fitzpatrick, D.J., Kilpatrick, J.M., and McWreath, Harry, 1990, Geohydrologic characteristics and simulated response to pumping stresses in the Sparta aquifer in east-central Arkansas: U.S. Geological Survey WaterResources Investigations Report 88-4201, 50 p.

Freiwald, D.A., 1985, Average annual precipitation and runoff for Arkansas, 1951-80: U.S. Geological Survey Water-Resources Investigations Report 84-4363, 1 sheet.

Hays, P.D., and Fugitt, D.T., 1999, The Sparta aquifer in Arkansas' critical ground-water areas-Response of the aquifer to supplying future water needs: U.S. Geological Survey Water-Resources Investigations Report 99-4075, 6 p.

Hays, P.D., Lovelace, J.K., and Reed, T.B., 1998, Simulated response to pumping stress in the Sparta aquifer of southeastern Arkansas and north-central Louisiana, 1998-2027: U.S. Geological Survey Water-Resources Investigations Report 98-4121, 25 p.

Holland, T.W., 1999, Water use in Arkansas, 1995: U.S. Geological Survey Open-File Report 99-188, 1 sheet.

Joseph, R.L., 1998, Potentiometric surface of the Sparta aquifer in eastern and south-central Arkansas and north-central Louisiana, and the Memphis aquifer in east-central Arkansas, October 1996-July 1997: U.S. Geological Survey Water-Resources Investigations Report 97-4282, 19 p.

Kilpatrick, J.M., 1992, Simulated response to future pumping in the Sparta aquifer, Union County, Arkansas: U.S. Geological Survey Water-Resources Investigations Report 91-4161, 25 p.

McDonald, M.G., and Harbaugh, A.W., 1988, A modular three-dimensional finite-difference ground-water flow model: U.S. Geological Survey Techniques of Water Resources Investigations, Book 6, Chapter A1, $586 \mathrm{p}$.

McWreath, H.C., III, Nelson, J.D., and Fitzpatrick, D.J., 1991, Simulated response to pumping stresses in the Sparta aquifer, northern Louisiana and southern Arkansas: Louisiana Department of Transportation and Development Water Resources Technical Report No. $51,51 \mathrm{p}$.

Orzol, L.L., and McGrath, T.S., 1992, Modifications of the U.S. Geological Survey modular finite-difference, ground-water flow model to read and write geographic information system files: U.S. Geological Survey Open-File Report 92-50, 202 p. 